\title{
Mutational spectrum of the CTNS gene in Italy
}

\author{
Silvia Mason ${ }^{1}$, Guglielmina Pepe ${ }^{2}$, Roberto Dall'Amico ${ }^{3}$, Sara Tartaglia ${ }^{1}$, \\ Stefania Casciani ${ }^{2}$, Marcella Greco ${ }^{5}$, Paola Bencivenga ${ }^{2}$, Luisa Murer ${ }^{4}$, Gianfranco Rizzoni ${ }^{5}$, \\ Romano Tenconi ${ }^{1}$ and Maurizio Clementi* ${ }^{1}$
}

\author{
${ }^{1}$ Clinical Genetics, Department of Pediatrics, University of Padua, Italy; ${ }^{2}$ Department of Internal Medicine, University \\ of Rome 'Tor Vergata', Ospedale Bambino Gesu', Rome, Italy; ${ }^{3}$ Pediatrics, Thiene Hospital, Italy; ${ }^{4}$ Nephrology, \\ Department of Pediatrics, University of Padua, Italy; ${ }^{5}$ Nephrology, Ospedale Bambino Gesu', Rome, Italy
}

Classic nephropathic or infantile cystinosis (NC) is an autosomal recessive disorder; the gene coding for the integral membrane protein cystinosin, which is responsible for membrane transport of cystine (CTNS), was cloned. Mutation analysis of the CTNS gene of Caucasian patients revealed a common 57-kb deletion, and several other mutations spread throughout the entire gene. In the present study, we report the CTNS mutations identified in $\mathbf{4 2}$ of $\mathbf{4 6}$ Italian families with NC. The percentage of mutations characterized in this study is $\mathbf{8 6 \%}$. The mutational spectrum of the Italian population is different from that of populations of North European origin: the $57-\mathrm{kb}$ deletion is present in a lower percentage, while the splicing mutations represent $30 \%$ of mutation detected in our sample. In all, six novel mutations have been identified, and the origin of one recurrent mutation has been traced.

European Journal of Human Genetics (2003) 11, 503-508. doi:10.1038/sj.ejhg.5200993

Keywords: cystinosis; mutations; Italian population; mutation origin

\section{Introduction}

Classic nephropathic or infantile cystinosis (NC) is an autosomal recessive disorder (MIM 219800) causing proximal renal tubular dysfunction because of lysosomal storage of free cystine resulting from impaired transport. ${ }^{1,2}$ It is the most common cause of renal tubular Fanconi syndrome in childhood, and is characterized by failure to thrive, polyuria and polydipsia, dehydration and hypophosphatemic rickets. Affected individuals develop renal failure at about 10 years of age. Patients suffer from a multisystem disease; therapy includes oral intake of free thiol cysteamine, which only slows down the course of the disease, and renal transplantation, which does not eliminate the accumulation of cystine in other organs.

*Correspondence: Dr M Clementi, Genetica Clinica ed Epidemiologica, Dipartimento di Pediatria, Via Giustiniani 3, Padova 35128, Italy. Tel. +390 498213 572; Fax: +390 498211 425;

E-mail maurizio.clementi@unipd.it

SM and GP contributed equally to this work.

Received 31 January 2002; revised 18 February 2003; accepted 20 February 2003
The cystinosis locus was first mapped to a 4-cM region of the short arm of chromosome 17p13 in 1995 by linkage analysis. ${ }^{3}$ Subsequent narrowing of this region initially enabled the identification of a deletion of the D17S829 marker and successively the isolation of the cystinosis gene, CTNS, ${ }^{4}$ which consists of 12 exons with the first methionine in exon 3. CTNS codes for a 367 amino-acid peptide, cystinosin, predicted to contain seven transmembrane domains (TM). Cystinosin is the lysosomal cystine transporter ${ }^{5}$ and it is sorted via a classic tyrosine-based GYDQL lysosomal sorting motif in its C-terminal tail, and a novel conformational lysosomal sorting motif in the fifth inter-TM loop. ${ }^{6}$

Previous studies performed in European- and Americanbased subpopulations of cystinosis patients identified many different mutations spread throughout the entire gene, the most frequent one being a large intragenic deletion that removes the first 10 exons plus a large amount of the upstream sequence. ${ }^{4,7-15}$

We report the CTNS mutations identified in 42 Italian patients with $\mathrm{NC}$, enrolled in the Italian Registry of NC. These data provide a basis for the molecular diagnosis of cystinosis in the Italian population. 


\section{Materials and methods}

Sources of data on NC patients were: the Italian Cystinosis Registry which includes 46 patients, reported by pediatric nephrology centers and metabolic units; the ITALKID Registry which includes all Italian children with renal insufficiency; the North Italian Transplant Registry, and the Registry of the Bracco pharmaceutical company which provides the patients with free drugs. Only subjects with classical NC, with clinical onset in early childhood, were included in the present study.

All NC patients and their families were asked to participate in this study. A total of 42 patients and their parents and unaffected sibs gave their informed consent.

Blood samples were collected from all study participants, and high molecular weight DNA was obtained from peripheral blood lymphocytes by standard phenol-chloroform extraction.

All DNA samples were initially screened for two previously described large $(\sim 57 \mathrm{~kb})$ and small $(\sim 13 \mathrm{~kb})$ deletions. CTNS coding exons and their flanking sequences in samples found to be heterozygous for the deletion, or in which the deletion was not detected, were amplified by the polymerase chain reaction (PCR) technique, and screened for mutations by the single-strand conformation polymorphism (SSCP) and the conformation-sensitive gel electrophoresis (CSGE) techniques, using different primers. The laboratory in Padova analyzed 27 samples by SSCP, and the laboratory in Rome analyzed the other 15 by CSGE; all samples in which one laboratory did not identify mutations were then analyzed by the other. To characterize the mutations, each sample displaying an abnormal SSCP/ CSGE band pattern was directly sequenced.

The samples in which no mutations were detected, using SSCP and CSGE techniques, underwent direct DNA sequencing of the entire CTNS coding region and of the promoter region.

\section{Detection of known deletions}

PCR was used to identify the intragenic deletions. PCR amplification was perfomed using $\mathrm{LDM}_{1}{ }^{16}$ and $\mathrm{P} 11^{17}$ primers. To ascertain the presence of a nondeleted allele, D17S829 primers were also included.

The $25 \mu \mathrm{l}$ reaction mixture contained $1 \times$ PCR buffer, $1.5 \mathrm{mM} \mathrm{MgCl}_{2}, 200 \mu \mathrm{M}$ dNTPs, $1 \mu \mathrm{M}$ of each primer, $1 \mathrm{U}$ Taq polymerase and $500 \mathrm{ng}$ of template DNA. In all, 30 cycles were run, consisting of $94^{\circ} \mathrm{C}$ for $30 \mathrm{~s}, 55^{\circ} \mathrm{C}$ for $40 \mathrm{~s}$ and $72^{\circ} \mathrm{C}$ for $1 \mathrm{~min}$. PCR products were electrophoresed on $7 \%$ polyacrylamide mini-gel and visualized by silver staining.

\section{SSCP analysis}

SSCP analysis was carried out on coding exons 3-12 using the primers described by Town et al, ${ }^{4}$ except for exons 3,4 ,
9, 10 and 12 where the following primers were respectively used:

5'-AACATTCCCCTGAACTTCTC- $3^{\prime}$ and 5'-CACCATTTC CCTCTTTACAA- $3^{\prime} \quad\left(T_{\mathrm{a}}=51^{\circ} \mathrm{C}\right) ; 5^{\prime}$-GACCCAGTGCCTCAT GTCA- $3^{\prime}$ and $5^{\prime}$-GCCAGGCCCAGGAACTTAC- $3^{\prime}\left(T_{\mathrm{a}}=57^{\circ} \mathrm{C}\right)$; $5^{\prime}$-GCCCCTCACCACCCAGCTT- $3^{\prime}$ and $5^{\prime}$-GTTGGCTGGG GTGGCCTGT-3' $\left(T_{\mathrm{a}}=62^{\circ} \mathrm{C}\right) ; \quad 5^{\prime}$-CCACATCTCTGCCCT CCT- $3^{\prime}$ and $5^{\prime}$-ACAGGGCCCTGGAGGTAC- $3^{\prime}\left(T_{\mathrm{a}}=62^{\circ} \mathrm{C}\right)$; $5^{\prime}$-GCCAACCTAACACCAGCTT- $3^{\prime}$ and $5^{\prime}$-GCCAGAGGCT GGGTACACT- $3^{\prime}\left(T_{\mathrm{a}}=56^{\circ} \mathrm{C}\right)$.

The amplification products were combined with formamide loading dye, denatured at $95^{\circ} \mathrm{C}$, and electrophoresed overnight on $8 \%$ polyacrylamide gel at $110-140 \mathrm{~V}$. Bands were visualized by silver staining.

\section{CSGE analysis}

CSGE analysis was also carried out on exons 3-12 according to Ganguly et $a l^{18}$ as described. ${ }^{19}$ Different primers were designed for exons 3,4 and 6 :

5'-ATTCCCCTGAACTTCTCTCT- $3^{\prime}$ and 5'-CCACCATTT CCCTCTTTACA-3' $\left(T_{\mathrm{a}}=51^{\circ} \mathrm{C}\right) ; 5^{\prime}$-CTGAACTCTGACCCAG TGCC- $3^{\prime}$ and $5^{\prime}$-CCTGAGCGGAGCTGAGCAC- $3^{\prime}\left(T_{\mathrm{a}}=63^{\circ} \mathrm{C}\right)$; $5^{\prime}$-TCCTCGGTAACTGTACGTGGC-3' and 5'-CCTTCTTGT CACGTGAGGCC-3' $\left(T_{\mathrm{a}}=63^{\circ} \mathrm{C}\right)$, respectively.

\section{CTNS Promoter region}

PCR of the CTNS promoter region was performed using the following primers: $5^{\prime}$ - CATGGAGGCTTCTCGTCTTC- $3^{\prime}$ and $5^{\prime}$-CGGCTAGACTTTGGGAGAGG-3' $\left(T_{\mathrm{a}}=58^{\circ} \mathrm{C}\right)$.

The $25 \mu \mathrm{l}$ reaction mixture contained $1 \times$ PCR buffer, $1.5 \mathrm{mM} \mathrm{MgCl}_{2}, 200 \mu \mathrm{M}$ dNTPs, $0.5 \mu \mathrm{M}$ of each primer, $1 \mathrm{U}$ Taq polymerase and $500 \mathrm{ng}$ of template DNA. In all, 35 cycles were run, consisting of $95^{\circ} \mathrm{C}$ for $30 \mathrm{~s}, 58^{\circ} \mathrm{C}$ for $40 \mathrm{~s}$ and $72^{\circ} \mathrm{C}$ for $40 \mathrm{~s}$.

\section{DNA sequencing}

The PCR products were purified using the High Pure PCR products Purification kit (Roche), and $30 \mathrm{ng}$ were sequenced using the Big Dye Terminator Cycle Sequencing kit (Perkin-Elmer), following the manufacturer's instructions. The sequencing reactions were run on an ABI 310 Automatic Sequencer (Perkin-Elmer).

\section{Results}

Patient information was provided by the collaborating centers and reported in Table 1 . In all, 22 patients were female and 20 male, ranging in age from 2 to 29 years. Of the 42 patients, 21 underwent dialysis between 5 and 13 years of age, and among these 11 underwent transplant between 7 and 13 years of age. Consanguinity was reported 
Table 1 Relevant data of studied patients

\begin{tabular}{|c|c|c|c|c|c|c|c|}
\hline$I D$ & $\begin{array}{l}\text { Age } \\
\text { (year) }\end{array}$ & $\begin{array}{l}\operatorname{Sex} \\
(M / F)\end{array}$ & $\begin{array}{l}\text { Age at diagnosis } \\
\text { (months) }\end{array}$ & $\begin{array}{l}\text { Age at dialysis } \\
\text { (year) }\end{array}$ & $\begin{array}{l}\text { Parental } \\
\text { consanguinity }\end{array}$ & Residence & $\begin{array}{l}\text { Mutation (HUGO } \\
\text { nomenclature) }\end{array}$ \\
\hline 1 & 8 & $\mathrm{~F}$ & 7 & 6 & No & NI (Pavia) & $\begin{array}{l}\text { c.569-577delTTCТССТСА } \\
\text { c.569-577delTTCТССТСА }\end{array}$ \\
\hline 2 & 12 & $\mathrm{~F}$ & uk & 5 & No & NI (Pavia) & $\begin{array}{l}\text { c.569-577delTTCTCCTCA } \\
\text { c.569-577delTTCTCСТCA }\end{array}$ \\
\hline 3 & uk & M & uk & b & First Cousins & $\mathrm{Cl}$ (Forli') & $\begin{array}{l}\text { del} 57 \mathrm{~kb} \\
\text { c. } 922 \mathrm{G}>\mathrm{A}\end{array}$ \\
\hline 4 & 10 & $\mathrm{~F}$ & 27 & 6 & No & $\mathrm{Cl}$ (Forli') & $\begin{array}{l}\text { del } 57 \mathrm{~kb} \\
\text { c. } 922 \mathrm{G}>\mathrm{A}\end{array}$ \\
\hline 5 & 16 & M & 14 & 9 & No & NI (Milano) & $\begin{array}{l}\text { del57 kb } \\
\text { del57 kb }\end{array}$ \\
\hline 6 & 23 & $\mathrm{~F}$ & 2 & 8 & No & NI (Milano) & $\begin{array}{l}\text { c. } 681+1 \mathrm{G}>\mathrm{A} \\
\text { c. } 696-697 \text { insC }\end{array}$ \\
\hline 7 & 4 & M & 13 & b & No & NI (Chiavenna Sondrio) & $\begin{array}{l}\text { del57 kb } \\
\text { del57 kb }\end{array}$ \\
\hline 8 & 17 & M & 48 & 12 & No & SI (Sapri Salerno) & $\begin{array}{l}\text { del13 kb } \\
\text { c. } 861 \mathrm{G}>\mathrm{A}\end{array}$ \\
\hline 9 & 7 & $\mathrm{~F}$ & 24 & b & uk & SI (Noci Bari) & $\begin{array}{l}\text { c. } 1015 \mathrm{G}>\mathrm{A} \\
\text { c. } 1015 \mathrm{G}>\mathrm{A}\end{array}$ \\
\hline 10 & 19 & $\mathrm{~F}$ & 12 & b & uk & $\mathrm{Cl}$ (Lucca) & $\begin{array}{l}\text { del13 kb } \\
\text { mnf }\end{array}$ \\
\hline 11 & 18 & $\mathrm{~F}$ & 60 & 8 & First cousins & SI (Matera) & $\begin{array}{l}\text { del } 57 \mathrm{~kb} \\
\text { c. } 681+1 \mathrm{G}>\mathrm{A}\end{array}$ \\
\hline 12 & 17 & M & 60 & 7 & uk & SI (Locri Reggio C.) & $\begin{array}{l}\text { c. } 1015 \mathrm{G}>\mathrm{A} \\
\text { c. } 1015 \mathrm{G}>\mathrm{A}\end{array}$ \\
\hline 13 & 4 & $\mathrm{~F}$ & 21 & b & uk & SI (Cava Dei Tirreni Salerno) & $\begin{array}{l}\text { c. } 225+3 A>T \\
\text { c. } 225+3 A>T\end{array}$ \\
\hline 14 & 18 & M & 17 & 5 & First cousins & SI (S. Arsenio Salerno) & $\begin{array}{l}\text { C. } 890 G>A \\
\text { mnf }\end{array}$ \\
\hline 15 & 17 & $\mathrm{~F}$ & 48 & 10 & uk & SI (Salerno) & $\begin{array}{l}\text { del13 kb; c. } 225+3 A>T \\
\text { c. } 225+3 A>T\end{array}$ \\
\hline 16 & 7 & $\mathrm{~F}$ & 10 & $\mathrm{~b}$ & uk & SI (Locri Reggio C.) & $\begin{array}{l}\text { del13 kb; c.1015G }>A \\
\text { c. } 1015 \mathrm{G}>\mathrm{A}\end{array}$ \\
\hline 17 & 14 & M & 14 & 9 & No & SI (Benevento) & mnf \\
\hline 18 & 6 & M & 24 & b & No & SI (Bari) & $\begin{array}{l}\mathrm{mnt} \\
\text { c. } 225+3 \mathrm{~A}>\mathrm{T} \\
\text { c. } 1015 \mathrm{G}>\mathrm{A}\end{array}$ \\
\hline 19 & 23 & M & 16 & b & No & NI (Gorizia) & $\begin{array}{l}\text { c.659-665delTCGTGCA } \\
\text { c. } 1015 G>A ;-295 G>C\end{array}$ \\
\hline 20 & 9 & $\mathrm{M}$ & 12 & b & No & SI (Caserta) & $\begin{array}{l}\text { c. } 225+3 \mathrm{~A}>\mathrm{T} \\
\text { c. } 225+3 \mathrm{~A}>\mathrm{T}\end{array}$ \\
\hline 21 & 4 & $\mathrm{~F}$ & 7 & b & No & $\mathrm{Cl}$ (Frosinone) & $\begin{array}{l}\text { c. } 681+1 G>A \\
\text { mnf }\end{array}$ \\
\hline 22 & 25 & M & 24 & $8.5^{c}$ & No & $\mathrm{Cl}$ (Perugia) & $\begin{array}{l}\text { del } 57 \mathrm{~kb} \\
\text { c. } 1015 \mathrm{G}>\mathrm{A}\end{array}$ \\
\hline 23 & 5 & $\mathrm{~F}$ & 13 & b & No & $\mathrm{Cl}$ (Frosinone) & $\begin{array}{l}\mathrm{mnf} \\
\mathrm{mnf}\end{array}$ \\
\hline 24 & 8 & $\mathrm{~F}$ & 48 & b & No & $\mathrm{Cl}$ (Frosinone) & $\begin{array}{l}\text { c. } 681+1 \mathrm{G}>\mathrm{A} \\
\text { c. } 1009 \mathrm{G}>\mathrm{A}\end{array}$ \\
\hline 25 & 18 & $\mathrm{~F}$ & 8 & $11^{\mathrm{c}}$ & No & $\mathrm{Cl}$ (Teramo) & $\begin{array}{l}\text { c. } 681+1 \mathrm{G}>\mathrm{A} \\
\text { c. } 681+1 \mathrm{G}>\mathrm{A}\end{array}$ \\
\hline 26 & 16 & $M$ & 18 & $10.5^{c}$ & No & $\mathrm{Cl}$ (Perugia) & $\begin{array}{l}\text { c.18-21delGACT } \\
\text { c.699-700delGT }\end{array}$ \\
\hline 27 & 22 & $M$ & 18 & $7.5^{\mathrm{c}}$ & No & $\mathrm{Cl}$ (Viterbo) & $\begin{array}{l}\text { c. } 922 \mathrm{G}>\mathrm{A} \\
1366 \mathrm{del} 12 \mathrm{bp}\end{array}$ \\
\hline 28 & 10 & M & 11 & b & First cousins & $\mathrm{Cl}$ (Frosinone) & $\begin{array}{l}\text { c.18-21delGACT } \\
\text { c.18-21delGACT }\end{array}$ \\
\hline 29 & 22 & M & 36 & $7^{c}$ & No & $\mathrm{Cl}$ (Chieti) & $\begin{array}{l}\text { c. } 681+1 \mathrm{G}>\mathrm{A} \\
\text { c. } 681+1 \mathrm{G}>\mathrm{A}\end{array}$ \\
\hline 30 & 17 & M & 17 & $7^{c}$ & No & $\mathrm{Cl}$ (Roma) & $\begin{array}{l}\text { c. } 516-517 \text { ins } C \\
\text { c. } 681+1 G>A\end{array}$ \\
\hline 31 & 14 & $\mathrm{~F}$ & uk & b & No & SI (Salerno) & $\begin{array}{l}\mathrm{mnf} \\
\mathrm{mnf}\end{array}$ \\
\hline 32 & 12 & $\mathrm{~F}$ & 18 & b & No & $\mathrm{Cl}$ (Ascoli) & $\begin{array}{l}\text { c. } 681+1 \mathrm{G}>\mathrm{A} \\
\text { c. } 681+1 \mathrm{G}>\mathrm{A}\end{array}$ \\
\hline
\end{tabular}


Table 1 (continued)

\begin{tabular}{|c|c|c|c|c|c|c|c|}
\hline$I D$ & $\begin{array}{l}\text { Age } \\
\text { (year) }\end{array}$ & $\begin{array}{l}\operatorname{Sex} \\
(M / F)\end{array}$ & $\begin{array}{l}\text { Age at diagnosis } \\
\text { (months) }\end{array}$ & $\begin{array}{l}\text { Age at dialysis } \\
\text { (year) }\end{array}$ & $\begin{array}{l}\text { Parental } \\
\text { consanguinity }\end{array}$ & Residence & $\begin{array}{l}\text { Mutation (HUGO } \\
\text { nomenclature) }\end{array}$ \\
\hline 33 & 9 & M & 23 & b & No & $\mathrm{Cl}$ (Pescara) & $\begin{array}{l}\text { c. } 681+1 \mathrm{G}>\mathrm{A} \\
\text { c. } 699-700 \mathrm{delGT}\end{array}$ \\
\hline 34 & 21 & $\mathrm{~F}$ & 12 & $7.5^{\mathrm{c}}$ & No & $\mathrm{Cl}$ (Teramo) & $\begin{array}{l}\text { C. } 681+1 \mathrm{G}>\mathrm{A} \\
\text { C. } 681+1 \mathrm{G}>\mathrm{A}\end{array}$ \\
\hline 35 & 8 & $\mathrm{~F}$ & uk & b & No & NI (Palmanova Udine) & $\begin{array}{l}-295 G>C \\
m n f\end{array}$ \\
\hline 36 & 18 & M & 8 & $12^{\mathrm{c}}$ & No & NI (Padova) & $\begin{array}{l}\text { del } 57 \mathrm{~kb} \\
\text { c. } 18-21 \text { delGACT }\end{array}$ \\
\hline 37 & 5 & $\mathrm{~F}$ & 9 & b & No & NI (Raveo Udine) & $\begin{array}{l}\text { c. } 681+1 G>A \\
\text { c. } 1015 G>A ;-295 G>C\end{array}$ \\
\hline 38 & 16 & $\mathrm{~F}$ & 9 & $8^{c}$ & No & $\mathrm{NI}$ (Udine) & $\begin{array}{l}\text { c. } 1015 \mathrm{G}>A ;-295 \mathrm{G}>C \\
\text { c. } 1015 \mathrm{G}>\mathrm{A} ;-295 \mathrm{G}>\mathrm{C}\end{array}$ \\
\hline 39 & 19 & $\mathrm{~F}$ & $<24$ & c & No & NI (Magnano In R. Udine) & $\begin{array}{l}\text { del } 57 \mathrm{~kb} \\
\text { c. } 1015 \mathrm{G}>\mathrm{A} ;-295 \mathrm{G}>\mathrm{C}\end{array}$ \\
\hline 40 & 4 & M & 12 & b & No & $\mathrm{NI}$ (Como) & $\begin{array}{l}\text { c. } 18-21 \text { delGACT } \\
\text { c. } 1015 \mathrm{G}>\mathrm{A}\end{array}$ \\
\hline 41 & 2 & M & 18 & b & No & SI (Sciacca Agrigento) & $\begin{array}{l}\text { c. } 1015 G>A \\
\text { c. } 1015 G>A\end{array}$ \\
\hline 42 & 29 & $\mathrm{~F}$ & uk & $13^{c}$ & Adopted & uk & $\begin{array}{l}\mathrm{mnf} \\
\mathrm{mnf}\end{array}$ \\
\hline
\end{tabular}

${ }^{a}$ Nomenclature as recommended by Antonorakis. ${ }^{24}$ bNo dialysis. ${ }^{~}$ Transplanted. mnf, mutation not found; NI, North Italy; Cl, Central Italy; SI, South Italy; uk, unknown

for four families only. When known, the geographical origin of the grand parents was also recorded.

PCR-based amplification using $\mathrm{LDM}_{1}, \mathrm{P} 11$ and D17S829 primers detected 14 deletions (10 cases of $57 \mathrm{~kb}$ and four of 13-kb deletion); nine of 10 large deletions were found in probands from North or Central Italy, while three of four small ones in probands from South Italy. Two patients were homozygous for the 57-kb deletion. SSCP and CSGE analyses were followed by sequencing of samples showing an abnormal band pattern; 15 mutated alleles were identified by SSCP, and 23 by CSGE, for a total detection of 38 mutated alleles.

Regarding the 32 remaining alleles (both alleles in 11 patients, one allele in 10) both techniques failed to detect any mutation.

Even if different conditions of SSCP/CSGE analysis were performed (ie concentration of acrylamide, addition of glycerol, gel length), by using these techniques, we found an unexpectedly low frequency of mutation detection. The 21 patients for whom both techniques failed to detect mutation, in one or both of their alleles, were asked to continue the analysis by sequencing the entire coding region of CTNS gene and the promoter region. All but four (\#21, 23, 31 and 42) accepted and sequencing allowed the detection of a further 19 mutated alleles and of the previously described $-295 \mathrm{G}>\mathrm{C}$ substitution in six promoters. ${ }^{20}$

Among the 16 different mutations detected, six were novel as reported in Table 2 . The c. $861 \mathrm{G}>\mathrm{A}$ is probably a pathogenic mutation; in fact, although it maintains the amino-acid charge (M287I), it was not observed in normal subjects.
In addition to the mutations, four apparent polymorphisms were identified. Two of these are silent mutations (c.504A $>$ G, already described by Shotelersuk et $a{ }^{7}{ }^{7}$ and c. $885 \mathrm{G}>\mathrm{A}$ ), while the $329+22 \mathrm{G}>\mathrm{C}$ is intronic; the c.779T $>C$ causes an amino-acid change (I260T), but all were present in patients who also manifested two pathogenic mutations.

\section{Discussion}

Cystinosis is a rare disease because of a lysosomal membrane transporter defect. After the CTNS gene was mapped and cloned, several mutations were identified in European and American patients. ${ }^{4,7-15}$

Some phenotypic correlation has been reported, and disease severity appears correlated to the expression of the gene product cystinosin. ${ }^{8,15,21,22}$ Infantile cystinosis is because of a homozygous or compound heterozygous state of deletions or mutations causing truncated protein or involving the TM domains.

The $57-\mathrm{kb}$ deletion accounts for about $50 \%$ of cystinotic chromosomes in European populations, while a study in French-Canadian patients showed a much lower frequency, reflecting an Irish origin. No hot spots have been observed, although some mutations appear to be common.

Previous studies, however, included heterogeneous groups of patients, and only four were performed in small homogeneous populations (from French-Canada, Brittany, The Netherlands and Switzerland-Germany). The present population study includes most Italian NC patients. Records appear complete, as all possible 
Table 2 Mutations in CTNS gene identified in Italian patients

\begin{tabular}{|c|c|c|c|c|}
\hline Position & No. alleles & Mutation & Mutation (HUGO nomenclature) & Consequence of mutation \\
\hline Promoter & 6 & & $-295 G>C$ & Reduced promoter activity \\
\hline Exon 3 & 5 & 357delGACT & c.18-21 delGACT & STOP codon 13 \\
\hline Exons 4, 5 & 0 & & & \\
\hline Intron 5 & $7^{b}$ & $564+3 A>T$ & c. $225+3 \mathrm{~A}>\mathrm{T}$ & Spice \\
\hline Exon 6,7 & 0 & & & \\
\hline Exon 8 & $1^{\mathrm{b}}$ & 856ins C & c.516-517insC & STOP codon 225 \\
\hline Exon 9 & $\begin{array}{l}4 \\
1^{\mathrm{b}}\end{array}$ & $\begin{array}{l}\text { 908delTTCTCCTCA } \\
\text { 998delTCGTCCCA }\end{array}$ & c.569-577delTTCTCCTCA & $\begin{array}{l}\text { STOP codon } 190 \\
\text { STOP codon } 251\end{array}$ \\
\hline Intron 9 & 15 & $1020+1 G>A$ & c. $681+1 \mathrm{G}>\mathrm{A}$ & Splice, STOP codon 127 \\
\hline Exon 10 & 1 & 1035 ins $C$ & c.696-697insC & STOP codon 296 \\
\hline & $2^{\mathrm{b}}$ & 1038delGT & 699-700delGT & STOP codon 293 \\
\hline Exon 11 & $1^{\mathrm{b}}$ & $1229 \mathrm{G}>\mathrm{A}$ & c. $890 \mathrm{G}>\mathrm{A}$ & STOP codon 297 \\
\hline & 3 & $1261 \mathrm{G}>\mathrm{A}$ & c. $922 \mathrm{G}>\mathrm{A}$ & G308R \\
\hline Exon 12 & $1^{\mathrm{b}}$ & $1348 \mathrm{G}>\mathrm{A}$ & c. $1009 \mathrm{G}>\mathrm{A}$ & G337R \\
\hline & 16 & $1354 \mathrm{G}>\mathrm{A}$ & c. $1015 \mathrm{G}>\mathrm{A}$ & G339R \\
\hline & 1 & 1366-1377del12nt & c.1027-1038del & In-frame deletion of 4 aа \\
\hline Exon 1-3 & 4 & Del13 kb & & No transcription \\
\hline Exon $1-10$ & 10 & Del57 kb & & No transcription \\
\hline
\end{tabular}

${ }^{\mathrm{a}}$ The $\mathrm{A}$ of the ATG of the initiator Met codon in CDNA is denoted nucleotide $+1 .{ }^{24}$ bovel mutation. nt, nucleotide; aa, amino acid.

information sources were consulted: pediatric units, transplant registry and data from the pharmaceutical company offering free drugs to patients. Molecular analysis was performed in 42 of the 46 Italian families who consented to this study.

First, we screened the patients for the deletions. Only 14 chromosomes of $84(17 \%)$ carried a deletion. To explain the high proportion of deletions found in his population, Shotelersuk suggested that the short arm of chromosome 17 might be susceptible to deletions. ${ }^{7,23}$ Our data, as well as the French-Canadians results, in which a much lower proportion of deletions was detected, contrast with this hypothesis, and support the hypothesis that this mutation originated from Northern Europe; ${ }^{13,17}$ indeed, the $57-\mathrm{kb}$ mutation is not widespread in North Italy, while the $13-\mathrm{kb}$ deletion is present mainly in South Italy.

Mutations were then searched using two different methods. If none were detected by one laboratory using SSCP or CSGE as the first procedure, the DNA was analyzed with the alternative method and some different primers in a second screening step.

Screening analysis with the two techniques certainly improved the number of mutations detected in our study: the percentage of mutations characterized is 62\% (14 deletions and 38 mutations out of 84 alleles). The entire coding region of 17 patients, for whom both techniques failed to detect any mutation in one or both of their alleles, was sequenced, allowing the identification of a further 19 mutated alleles for a total of 71/84 alleles (84\%).

Mutations in the CTNS gene promoter were recently identified and it was suggested that they could partially account for the undetected mutations in the coding sequence. ${ }^{20}$ In order to exclude the presence of mutations in the CTNS gene promoter, this regulatory region was also sequenced in patients in which no mutations were detected by SSCP/CSGE analysis, allowing the detection of a previously described $-295 \mathrm{G}>\mathrm{C}$ substitution in five patients, all coming from a small region of Northern Italy (Friuli Venezia Giulia). Four of these carried two other pathological mutations. This observation suggests that more studies are necessary to establish the real pathogenicity of the $-295 \mathrm{G}>\mathrm{C}$ substitution.

Interestingly, this promoter base change is always inherited in cis with two polymorphisms (c.329+22G > C and c.779T $>$ C) detected only in these five patients, and with the c.1015G $>$ A in four of them. These findings enable us to define a typical haplotype of the patients coming from the North of the Friuli Venezia Giulia region.

All the data collected demonstrate that the mutational spectrum of the Italian population is different from that of populations of North European origin. ${ }^{11-13}$

In general, the $57-\mathrm{kb}$ deletion is present in a lower percentage, while the splicing mutations are 22/84 - higher than the figures reported in the literature. The recurrent mutation $753 \mathrm{G}>\mathrm{A}(\mathrm{W} 138 \mathrm{X})^{9}$ is not present in Italian patients, while two mutations appear to be frequent in our patients: the c. $1015 \mathrm{G}>\mathrm{A}$ (16 alleles) and the c. $681+1 \mathrm{G}>\mathrm{A}$ (15 alleles) single nucleotide substitutions.

The c.1015G $>$ A was identified for the first time in one allele of a compound heterozygous patient of Italian ancestry $^{7}$ and recently described as the most common cause of nephropathic cystinosis in the Ontario Amish Mennonite. ${ }^{10}$

The 16 alleles bearing the c.1015G $>$ A are clustered in two groups, one in Southern and one in Northern Italy, while nine of the 10 patients with the c.681+1G $>$ A come from Southern Italy. 
Our data confirm that the mutational spectrum of the CTNS gene is wide; the gene presents few common mutations probably because of founder's effect.

This observation raises the suspicion of parental consanguinity in patients homozygous for a specific mutation, as in our cases \#1, 2, 5, 7, 9, 12, 13, 20, 25, 28, 29, 32, 34, 38 and 41 . However, the family studies in most cases did not disclose a known parental consanguinity (Table 1), while surprisingly almost all affected patients reporting consanguinity were genetic compounds. This unexpected finding may be because of an unknown low-degree consanguinity or to a higher frequency of pathogenetic mutations in the CTNS locus.

\section{References}

1 Gahl WA, Bashan N, Tietze F, Bernardini I, Schulman JD: Cystine transport is defective in isolated leukocyte lysosomes from patients with cystinosis. Science 1982; 217: 1263-1265.

2 Gahl WA, Tietze F, Bashan N, Steinherz R, Schulman JD: Defective cystine exodus from isolated lysosome-rich fractions of cystinotic leucocytes. J Biol Chem 1982; 257: 9570-9575.

3 Cystinosis Collaborative Research Group: Linkage of the gene for cystinosis to markers on the short arm of chromosome 17. Nat Genet 1995; 10: 246-248.

4 Town M, Jean G, Cherqui S et al: A novel gene encoding an integral membrane protein is mutated in nephropathic cystinosis. Nat Genet 1998; 18: 319-324.

5 Kalatzis V, Cherqui S, Antignac C, Gasnier B: Cystinosin, the protein defective in cystinosis, is a $\mathrm{H}(+)$-driven lysosomal cystine transporter. EMBO J 2001; 20: 5940-5949.

6 Cherqui S, Kalatzis V, Trugman G, Antignac C: The targeting of cystinosin to the lysosomal membrane requires a tyrosinebased signal and a novel sorting motif. J Biol Chem 2001; 276: 13314-13321.

7 Shotelersuk V, Larson D, Anikster Y et al: CTNS mutations in an American-based population of cystinosis patients. Am J Hum Genet 1998; 63: 1352-1362.

8 Anikster Y, Shotelersuk V, Gahl WA: CTNS mutations in patients with cystinosis. Hum Mut 1999; 14: 454-458.

9 McGowan-Jordan J, Stoddard K, Podolsky L et al: Molecular analysis of cystinosis: probable Irish origin of the most common French Canadian mutation. Eur J Hum Genet 1999; 7: 671-678.

10 Rupar CA, Matsell D, Surry S, Siu V: A G339R mutation in the CTNS gene is a common cause of nephropathic cystinosis in the south western Ontario Amish Mennonite population. J Med Genet 2001; 38: 615-616.
11 Heil SG, Levtchenko E, Monnens LAH, Trijbels FJM, Van der Put NMJ, Blom HJ: The molecular basis of Dutch infantile nephropathic cystinosis. Nephron 2001; 89: 50-55.

12 Kalatzis V, Cherqui S, Jean G et al: Characterization of a putative founder mutation that accounts for the high incidence of cystinosis in Brittany. J Am Soc Nephrol 2001; 12: 2170-2174.

13 Kiehntopf M, Schickel J, Gonne Bv B et al: Analysis of the CTNS gene in patients of German and Swiss origin with nephropathic cystinosis. Hum Mutat 2002; 20: 237.

14 Kleta R, Anikster Y, Lucero C et al: CTNS mutations in African American patients with cystinosis. Mol Genet Metab 2001; 74: 332-337.

15 Kalatzis V, Cohen-Solal L, Cordier B et al: Identification of 14 novel CTNS mutations and characterization of seven splice site mutations associated with cystinosis. Hum Mut 2002; 20: 439-446.

16 Anikster Y, Lucero C, Touchman JW et al: Identification and detection of the common $65-\mathrm{kb}$ deletion breakpoint in the nephropathic cystinosis gene (CTNS). Mol Genet Metab 1999; 66: 111-116.

17 Forestier L, Jean G, Attard M et al: Molecular characterization of CTNS deletions in nephropathic cystinosis: development of a PCR-based detection assay. Am J Hum Genet 1999; 65: 353-359.

18 Ganguly A, Rock MJ, Prockop DJ: Conformation-sensitive gel electrophoresis for rapid detection of single-base differences in double-stranded PCR products and DNA fragments: evidence for solvent-induced bands in DNA heteroduplexes. Proc Natl Acad Sci USA 1993; 90: 10325-10329.

19 Pepe G, Giusti B, Attanasio M et al: Marfan syndrome: a report of three novel mutations in Italian patients. J Mol Cell Cardiol 1997; 29: $1877-1884$

20 Phornphutkul C, Anikster Y, Huizing M et al: The promoter of a lysosomal membrane transporter gene, CTNS, binds $\mathrm{Sp}-1$, shares sequences with the promoter of an adjacent gene, CARKL, and causes cystinosis if mutated in a critical region. Am J Hum Genet 2001; 69: 712-721.

21 Attard M, Jean G, Forestier L et al: Severity of phenotype in cystinosis varies with mutations in the CTNS gene: predicted effect on the model of cystinosin. Hum Mol Genet 1999; 8: 2507-2514.

22 Thoene J, Lemons R, Anikster Y et al: Mutations of CTNS causing intermediate cystinosis. Mol Genet Metab 1999; 67: 283-293.

23 Touchman JW, Anikster Y, Dietrich Nl et al: The genomic region encompassing the nephropathic cystinosis gene (CTNS): complete sequencing of a $200-\mathrm{kb}$ segment and discovery of a novel gene within the common cystinosis-causing deletion. Genome Res 2000; 10: 165-173.

24 Antonorakis SE and the Nomenclature Working group: Recommendations for a nomenclature system for human gene mutations. Hum Mutat 1998; 11: 1-3. 